\title{
A Preliminary Study of the Absorption, Metabolism and Excretion of Injectable Thiambutosine
}

\author{
G. A. ELLARD \\ From the Department of Biochemistry, University College, London, \\ and the East African Leprosy Research Centre, Busia, Tororo, Uganda
}

IN T R O D U C T I O N

Oral thiambutosine or $\mathrm{I}$-(p-dimethylaminophenyl)-3-(p-butoxyphenyl)-2-thiourea, also known as DPT, CIBA I 906 and SU I 9o6, is extensively used in the treatment of leprosy. Previous studies demonstrated that in man only about io per cent of oral doses of thiambutosine of up to I . $5 \mathrm{~g}$ are absorbed and that larger doses do not result in increased absorption. Maximum daily absorption (ca. $360 \mathrm{mg}$ ) can be achieved by giving I $5 \mathrm{~g}$ thiambutosine thrice daily. After absorption, the butoxy group of thiambutosine is rapidly metabolised and the water-soluble p-dimethylaminodiphenyl thioureas formed are rapidly excreted in the urine. About 75 per cent of the dose is excreted unchanged in the faeces (Ellard, r 96 г : Ellard and Naylor, r 96r ).

The possibility of giving thiambutosine by intramuscular injection was therefore investigated with a view to securing complete absorption of the drug. Two preparations of thiambutosine (20 per cent $\mathrm{w} / \mathrm{v}$ ) were supplied by CIBA Ltd., for intramuscular injection. The first consisted of an aqueous suspension and the second was a suspension in arachis oil. The treatment of leprosy with injections of thiambutosine in arachis oil has been described by several workers (Browne, I 965; Dubos and Limbos, I 962; Ross, I963). The excretion of thiambutosine and its metabolites has been measured in the urine and faeces of patients receiving these two preparations and the previous investigation of the metabolism of oral thiambutosine (Ellard, I96I) was extended to determine whether or not biliary excretion of thiambutosine and its metabolites occurs in man.

\section{METHODS}

Because of the uniform excretion of creatinine in man, the completeness of all 24-hr urine speci- mens was checked by determining their creatinine content by the method of King and Wootton ( 1956$)$.

The amounts of thiambutosine and its metabolites (water-soluble p-dimethylaminodiphenyl thioureas) excreted in the urine of patients receiving injectable thiambutosine were measured by two methods:

(a) Half of each 24-hr urine collection was diluted to I.5 L. Aliquots ( I $00 \mathrm{ml}$ ) of diluted urine were then acidified with glacial acetic acid ( $\mathrm{I} \mathrm{ml}$ ) and thiambutosine and its metabolites extracted into benzene/ethyl acetate (I : I) $(2 \times 10 \mathrm{ml})$ after the addition of ammonium sulphate $(5 \circ \mathrm{g})$. When the concentration of thiambutosine and its metabolities in the diluted urine was less than $4 \mu \mathrm{g} / \mathrm{ml}, 200 \mathrm{ml}$ aliquots of urine were acidified with acetic acid $(2 \mathrm{ml})$ and extracted with Io $\mathrm{ml}$ benzene/ethyl acetate (I : I) after the addition of ammonium sulphate ( $\mathrm{I}$ OO g). Up to $2 \mathrm{ml}$ of the benzene/ethyl acetate extract, containing $\mathrm{ro}-40 \mathrm{og}$ p-dimethylaminodiphenyl thioureas, were pipetted into a test tube marked at $\mathrm{r}$ o $\mathrm{ml}, 6 \mathrm{ml}$ ethanol added and made to the mark with 0.5 per cent acetic acid. Af ter reaction with 0 . I $\mathrm{ml} 20$ per cent $(\mathrm{w} / \mathrm{v})$ ferric chloride, the density of the blue colour formed was read within 30 seconds in an 'EEL' colorimeter with a No. 608 or $\mathrm{OB}_{\mathrm{I}}$ filter, against a reagent blank of $\mathrm{I} \mathrm{ml}$ 0.5 per cent acetic acid and 0 . I ml ferric chloride. Since the metabolites of thiambutosine do not extract quantitatively into benzene/ethyl acetate ( I : I ), calibration curves relating the final colorimeter reading to the initial concentration of thiambutosine metabolites were constructed in the following manner:

24-hr blank urines from three patients were pooled and diluted to $9 \mathrm{~L}$. 24-hr thiambutosineurines from three other patients, who were receiving $\mathrm{I} .5 \mathrm{~g}$ thiambutosine orally thrice daily, 
were pooled and the p-dimethylaminodiphenyl thiourea content determined by reaction with ferric chloride as described previously (Ellard, i 96I). The pooled thiambutosine urine, which contained I . 44 g p-dimethylaminodiphenyl thioureas was then diluted to $9 \mathrm{~L}$ so that the final concentration of thiambutosine and its metabolites was $160 \mu \mathrm{g} / \mathrm{ml}$. Aliquots of the diluted thiambutosine-urine and blank urine were then mixed in various proportions to give urine samples containing I-I $60 \quad \mu \mathrm{g} / \mathrm{ml}$ p-dimethylaminodiphenyl thioureas. These were then extracted and reacted as described above.

Using this method it was possible to measure a daily excretion in the urine of as little as $3 \mathrm{mg}$ thiambutosine and its metabolites (i.e. a concentration of I $\mu \mathrm{g} / \mathrm{ml}$ p-dimethylaminodiphenyl thioureas in the diluted 24-hr urine).

(b) When the excretion of thiambutosine and its metabolites exceeded $120 \mathrm{mg} /$ day, the method described previously (Ellard, I96 I) was also used. The results obtained by the two methods agreed to within about ro per cent.

\section{Paper chromatography}

Descending chromatography on Whatman No. 4 paper was used. In each case io $\mu \mathrm{g}$ p-dimethylaminodiphenyl thiourea was applied to the paper.

The solvent systems employed were as follows:

No. I Pyridine/n butanol/ io per cent ammonia (2: I: I), run for $4 \mathrm{hr}$.

No. 2 Ethyl acetate/ benzene/ water (I: I : I), run for $2 \mathrm{hr}$. (Smith and Williams, I96r).

No. $3 \mathrm{n} \mathrm{Butanol} /$ ethanol/ $3 \mathrm{~N}$ ammonium carbonate buffer (40: I I : i 9), run for $5^{-6}$ hr. (Fewster and Hall, i 95I).

No. 4 Benzene/ acetic acid/water (4:4: I), run $4 \mathrm{hr}$ (modified from El Masri, Smith and Williams, 1956).

No. 5 Ammonium acetate buffer $\mathrm{pH} 4.0$ (o. I M), run for $2 \mathrm{hr}$.

p-Dimethylamino-diphenyl thioureas were detected on the chromatograms as blue spots by spraying with ro per cent $(w / v)$ ferric chloride (Smith and Williams, ig6r). The detection of the spots was improved by washing the papers with water one minute after spraying with ferric chloride.
RESULTS

(i) Excretion of p-dimethylaminodiphenyl thioureas in the urine after intramuscular injection of an aqueous suspension of thiambutosine (20 per cent w/v).

Four patients were given 23-29 injections of thiambutosine during a period of $30-40$ days. The mean excretion of p-dimethylaminodiphenyl thioureas in the urine is shown in Fig. I and the results from the individual patients are summarised in Table I. (N.B.-For convenience 'DPT' is used instead of 'thiambutosine' in the figures and tables).

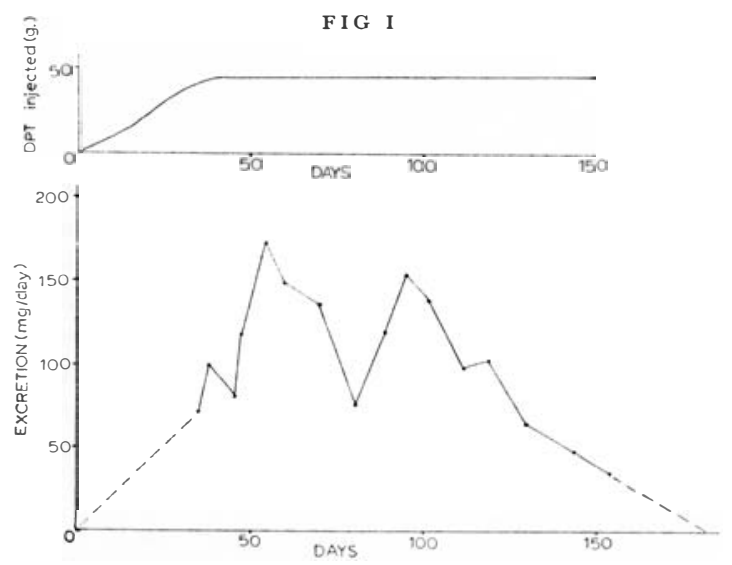

Excretion of DPT and its Metabolites af ter Intramuscular Injection of an Aqueous Suspension of DPT $(20 \% \mathbf{w} / \mathbf{v})$

TABLE I

The Excretion of p-Dimethylaminodiphenyl Thioureas in the Urine af ter Intramuscular Injection with an Aqueous Suspension of Thiambutosine

\begin{tabular}{|c|c|c|c|}
\hline $\begin{array}{l}\text { Patient } \\
\text { No. }\end{array}$ & $\begin{array}{l}D P T \\
\text { injected } \\
g\end{array}$ & $\begin{array}{l}\text { Total excretion } \\
\text { p-dimethylamino- } \\
\text { diphenyl thioureas } \\
g\end{array}$ & $\begin{array}{l}\% \text { dose } \\
\text { recovered }\end{array}$ \\
\hline I & 39 & I 3.2 & 34 \\
\hline 2 & 44 & 17.7 & 40 \\
\hline 3 & 44 & I $2 . \mathrm{I}$ & 28 \\
\hline 4 & $5^{I}$ & I 2.3 & 24 \\
\hline
\end{tabular}

(ii) Excretion of p-dimethylaminodiphenyl thioureas in the urine after intramuscular injection of thiambutosine (20 per cent w/v) in arachis oil.

Six patients were given 7-9 injections of thiambutosine during a period of $9-$ I I days. The mean excretion of p-dimethylaminodiphenyl thioureas in the urine is shown in Fig. 2 and the results for 
the individual patients are summarised in Table 2.

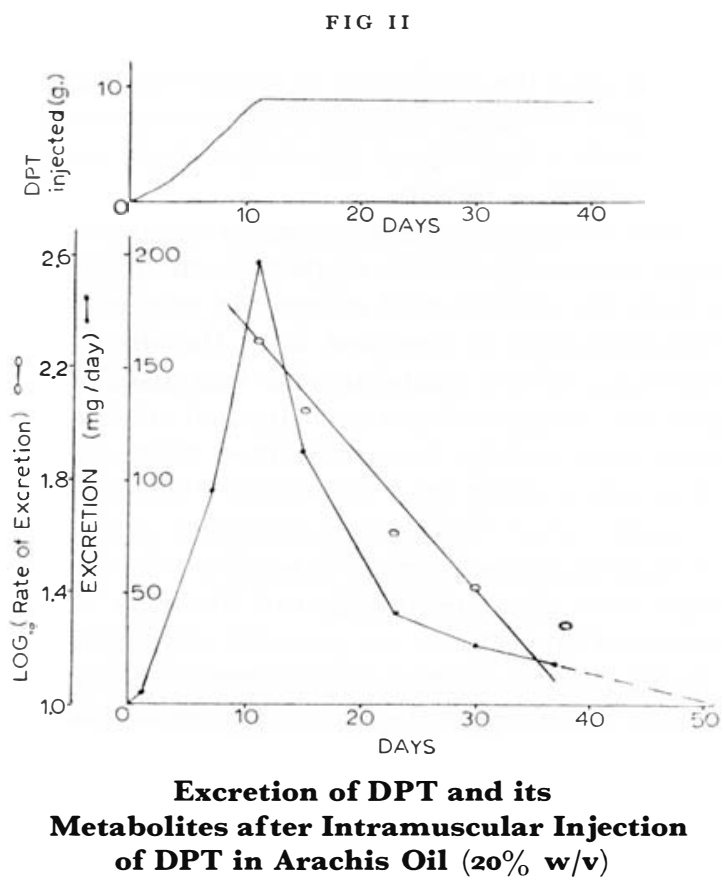

T A B L E II

The Excretion of p-Dimethylaminodiphenyl Thioureas in the Urine after Intramuscular Injection with a Suspension of Thiambutosine in Arachis Oil

\begin{tabular}{llll}
\hline $\begin{array}{l}\text { Patient } \\
\text { No. }\end{array}$ & $\begin{array}{l}\text { DPT } \\
\text { injected } \\
g\end{array}$ & $\begin{array}{l}\text { Total excretion } \\
\text { p-dimethylamino- } \\
\text { diphenyl thioureas } \\
g\end{array}$ & $\begin{array}{l}\text { \% dose } \\
\text { recovered }\end{array}$ \\
\hline 5 & 8.4 & 2.72 & 32 \\
6 & 9.6 & 1.32 & 14 \\
7 & 9.6 & 2.35 & 25 \\
8 & 9.6 & 3.49 & 36 \\
9 & 6.8 & 2.80 & 4 I \\
I0 & 9.6 & 1.83 & 19 \\
\hline
\end{tabular}

(iii) Excretion of thiambutosine and its metabolites in the urine and faeces after repeated oral dosage with thiambutosine.

Urine was collected for I I days and faeces for $2 \mathrm{I}$ days from a subject who received $\mathrm{I} .5 \mathrm{~g}$ thiambutosine orally thrice daily for I I consecutive days. A total of $5.45 \mathrm{~g}$ p-dimethylaminodiphenyl thioureas were excreted in the urine (I I per cent of the dose). These compounds were shown by countercurrent distribution techniques to consist almost entirely of water-soluble metabolites of thiambutosine and the least polar metabolite was found to be the 'CIBA Propoxy acid' (Ellard, to be published). This compound is also an important metabolite of the drug in the rabbit (Smith and Williams, I 96 I ). It is obtained by terminal oxidation of the butoxy group of thiambutosine. The amount of thiambutosine excreted unchanged in the urine was estimated at about $45 \mathrm{mg}$ (about o. I per cent of the dose).

The faeces were repeatedly extracted with acetone until no more ferric chloride-reacting material could be extracted and the p-dimethylaminodiphenyl thioureas content of the extract determined by reacting with ferric chloride in the presence of 60 per cent ethanol as described in method (a). The excretion of p-dimethylaminodiphenyl thioureas in the faeces, which had ceased completely io days after the last dose, totalled $39.9 \mathrm{~g}$ or $8 \mathrm{I}$ per cent of the dose. Thus in this study it was possible to account for at least 92 per cent of the administered thiambutosine.

Acetone extracts of the faeces were chromatographed in five solvents using thiambutosine, synthetic 'CIBA Propoxy acid' and thiambutosine metabolites (thiambutosine-urine) as markers. The results are summarised in Table 3. In each solvent the ferric chloride-reacting material extracted from the faeces moved as a single spot with an Rfidentical to that of unchanged thiambutosine, and could be distinguished from the 'CIBA propoxy acid' and the other major metabolites of thiambutosine excreted in the urine.

T A B L E III

Rf-Values of an Extract of Thiambutosine-Faeces and related Compounds

\begin{tabular}{lllll}
\hline Solvent & DPT & $\begin{array}{l}\text { Extract } \\
\text { DPT-faeces }\end{array}$ & DPT-urine & $\begin{array}{l}\text { PIBA } \\
\text { Dropoxy acid }\end{array}$ \\
\hline I & 0.97 & 0.97 & 0.80 & 0.83 \\
2 & 0.96 & 0.96 & $0.9 \mathrm{I}$ & 0.93 \\
3 & 0.98 & 0.98 & 0.47 & $0.5^{6}$ \\
4 & 0.90 & 0.89 & 0.37 & $0.5^{0}$ \\
5 & 0 & 0 & $0.7 \mathrm{I}$ & $0.7 \mathrm{I}$ \\
& \multicolumn{5}{r}{ and slight trail } \\
\end{tabular}

Other studies showed that the 'CIBA Propoxy acid' has a partition coefficient of $\mathrm{I} .3 \pm 0.2$ in benzene/ ph 4.0 acetate buffer $(\mathrm{o} .2 \mathrm{M})$ and less than 0.02 in benzene/o. IN NaOH at $25^{\circ}$. Thiambutosine has a partition coefficient of greater than I, ooo in both these solvent systems. 
$50 \mathrm{ml}$ of an acetone extract of thiambutosinefaeces, containing $420 \mathrm{mg}$ p-dimethylaminodiphenyl thioureas, was evaporated to dryness using a rotary evaporator and the residue extracted with benzene $(3 \mathrm{x} 20 \mathrm{ml})$ after the addition of $\mathrm{ro} \mathrm{ml} \mathrm{pH} 4.0$ acetate buffer. The p-dimethylaminodiphenyl thioureas were quantitatively extracted into benzene $($ I oo \pm 2 per cent), less than 0.3 per cent remaining in the aqueous phase. On shaking the benzene extract twice with an equal volume of o. I N NaOH, less than I per cent of the p-dimethylaminodiphenyl thioureas were removed. It must therefore be concluded that the ferric chloride-reacting material excreted in the faeces after oral dosage with thiambutosine consists entirely of the unchanged drug.

\section{ISGUSSION}

It should be emphasized that the results presented in this paper are only preliminary and need confirmation. It should also be noted that the dosage regimens employed in this pharmacological study are very different from those in general clinical use, when weekly or fortnightly injections of $\mathrm{I}-2 \mathrm{~g}$ of thiambutosine are given in arachis oil.

When thiambutosine was given by intramuscular injection in an aqueous suspension, it was absorbed extremely slowly from the depot (Fig. I). The daily excretion of thiambutosine and its metabolites in the urine did not reach I oo mg until a total of about $40 \mathrm{~g}$ of the drug had been injected. No further thiambutosine was given, but the excretion of thiambutosine and its metabolites continued with little diminution for over two months. It was still possible to demonstrate the excretion of p-dimethylaminodiphenyl thioureas in the urine four months later.

When a suspension of thiambutosine in arachis oil was used for intramuscular injection, the absorption of the drug from the depot was much more rapid (Fig. 2). This is probably due to the greater solubility of thiambutosine in arachis oil than in water. The solubility of thiambutosine in arachis oil at $37^{\circ}$ was estimated at about $25^{\circ}$ $\mu \mathrm{g} / \mathrm{ml}$ and in aqeous acetate and phosphate buffers ( $\mathrm{pHs} 5-7$ ) at about I $4 \mathrm{\mu g} / \mathrm{ml}$. After about I $\mathrm{g}$ thiambutosine had been injected in arachis oil, the daily excretion of p-dimethylaminodiphenyl thioureas in the urine rose to about 200 mg, and in one patient (No. 8) it reached 400 mg. This is similar to the maximum urinary excretion during oral dosage (Ellard, I96I). Injections of thiambutosine were then discontinued and the excretion of p-dimethylaminodiphenyl thioureas decreased almost exponentially, with a half-life of about 6-7 days, to low levels within a month.

The different pharmacological properties of these two preparations emphasise the extent 10 which the vehicle used affects the rate at which thiambutosine is absorbed from the site of the injection. When thiambutosine was dissolved in polyethyleneglycol-40o and injected subcutaneously into rabbits, it was absorbed more rapidly than when given in a suspension (Schmid and Tripod, I 959). The pharmacological properties of thiambutosine injected in arachis oil may also vary with the concentration of the drug in the preparation, since a 20 per cent suspension of thiambutosine controls experimental tuberculcsis in mice more effectively than the same amount of drug injected as a 5 per cent suspension (Kradolpher and Schmid, I 962).

The total excretion of p-dimethylaminodiphenyl thioureas in the urine after injection of thiambutosine never exceeded 4I per cent of the administered dose (Tables I and 2). The following possible explanations are considered:

( I) Biliary excretion of thiambutosine of its metabolites.

Schmid and Tripod (I959) have shown that when thiambutosine is injected intravenously into the rabbit, the drug or its metabolites are excreted in the bile and through the intestinal wall. However when thiambutosine was given subcutaneously, dissolved in polyethyleneglycol400 or as a suspension, measurable concentrations of the drug or its metabolites could not be detected in the faeces.

A 24-hr collection of faeces was made from one of the patients receiving the aqueous suspension of thiambutosine by in tramuscular injection, who was excreting over roo mg p-dimethylaminophenyl thioureas in the urine each day. Less than $2 \mathrm{mg}$ p-dimethylaminophenyl thioureas could be detected in the faeces. If biliary excretion of thiambutosine or its metabolites had been responsible for the discrepancy between the amount of thiambutosine injected and the p-dimethylaminodiphenyl thioureas excreted in the urine, the biliary excretion of thiambutosine and 
its metabolites would have averaged over I 70 $\mathrm{mg} /$ day during the whole six months period.

Williams, Millburn and Smith ( I965) studied the biliary excretion of a number of foreign compounds in the rat and showed that the compounds excreted to the greatest extent in the bile were polar conjugates of large molecules. Thiambutosine was not excreted unchanged in the bile but as two metabolites which appeared to be glucuronides. Since over 99 per cent of the p-dimethylaminodiphenyl thioureas excreted in the urine of patients receiving oral thiambutosine consist of water-soluble metabolites of the drug, it might be anticipated that biliary excretion would lead to the elimination of metabolites of thiambutosine in the faeces. The fact that no such metabolites could be demonstrated in the faeces after oral dosage with thiambutosine strengthens the conclusion that biliary excretion of thiambutosine and its metabolites is of no importance in man. It is possible however that small amounts of thiambutosine metabolites are excreted in the bile and then quantitatively reabsorbed from the gut.

Emerson and Nicholson ( 1965 ) have studied the absorption of orally administered p, p'diisoamyloxydiphenyl thiourea (Isoxyl) in man using ${ }^{35}$ S-labelled drug. At a dose of $6 \mathrm{~g} /$ day, in divided doses, the absorption of this diphenyl thiourea is also very limited. Less than 2 per cent of the dose was excreted in the urine and less than 0.2 per cent in the bile.

(2) Metabolism of thiambutosine to compounds not estimated by ferric chloride.

When thiambutosine is given orally, all the metabolites of the drug can be estimated by reaction with ferric chloride (Ellard and Naylor, I 96 I ). Although the metabolic fate of compounds in the body is usually relatively unaffected by the amount of drug metabolised, it is possible that when small amounts of thiambutosine are continuously absorbed from the site of injection, a significant proportion of the drug may be metabolised to compounds that could not be determined by the methods employed in these studies. Such a possibility can only be answered by using isotopically labelled thiambusotine.

(3) Incomplete absorption of thiambusotine from the site of injection.

Owing to the extremely low solubility of thiambusotine in water (about $\mathrm{I} .4 \mathrm{\mu g} / \mathrm{ml}$ at pHs $5^{-7}$ and $37^{\circ}$ ) it is possible that a considerable proportion of the thiambutosine deposited at the site of injection remains unabsorbed. There is some evidence from animal experiments supporting this possibility. Schmid and Tripod (I959) injected rabbits subcutaneously with thiambutosine, dissolved in polyethyleneglycol-40o or as a suspension. Under these conditions the drug was incompletely absorbed. After six days only about 2 I per cent (solution) and 7 per cent (suspension), respectively, of the dose was excreted in the urine and some of the drug still persisted at the site of injection (percentages excreted calculated from Fig. 6 of Schmid and Tripod, I 959). In the mouse 6 per cent of the drug could be recovered from the site of injection 20 days after subcutaneous dosage (Kradolpher and Schmid, r 962). It should be possible to make a direct study of the extent and rapidity of the absorption of injectable thiambutosine in man by measuring the concentrations of thiambutosine in biopsies taken from the site of injection after various time intervals.

\section{S UMM AR Y}

I. An aqueous suspension of injectable thiambutosine was absorbed extremely slowly and metabolites of thiambutosine could be demonstrated in the urine four months after injections of the drug had been discontinued.

2. Absorption was accelerated when thiambutosine was injected in arachis oil, its half-life in the body being reduced to about 6-7 days.

3. The total excretion of thiambutosine and its metabolites never exceeded $4 \mathrm{I}$ per cent of the injected dose and it is possible that the drug was incompletely absorbed from the site of injection. 4. Thiambutosine or its metabolites could not be detected in the faeces in significant amounts after intramuscular injection of the drug, and it was concluded that biliary excretion of these compounds is not important in man.

A GKNOWLEDGEMENTS

I should like to thank Dr J. M. B. Garrod for giving the patients injectable thiambutosine; Mrs P. H. Clarke and Dr R. J. W. Rees for their helpful advice during the preparation of this paper; and the Secretary General, East Africa Common Services Organisation for permission to publish. My thanks are also due to CIBA Ltd., for supplies of injectable thiambutosine and to the Medical Research Council and the British Leprosy Relief Association for financial assistance. 


\section{REFERENCES}

BRowne, s. G. (I965). A limited clinical trial of injectable thiambutosine (Ciba I 9o6). Leprosy Rev., 36, 2 I-22.

Dubos, A. and Limbos, P. ( I962). Quelques essais du I 906 (DPT) dans le traitment de la lèpre chez l'Européen. Ann. Soc. Belge de Méd. Trop., 42, 307-3ig.

Ellard, G. A. (I96I). The absorption, metabolism and excretion of $\mathrm{I}-(\mathrm{p}-\mathrm{dimethylaminophenyl})-3-(\mathrm{p}-\mathrm{butoxy}-$ phenyl)-2-thiourea in man. Part I. A study using colorimetric methods. Leprosy Rev., 32, 233-248.

Ellard, G. A. and NAYLOR, R. F. (I96I). The absorption, metabolism and excretion of $\mathrm{I}$-(p-dimethylaminophenyl)3-(p-butoxyphenyl)2-thiourea in man. Part 2. A study using ${ }^{35}$ S-labelled drug. Leprosy Rev., 32, pF. 249-258.

El masri, A. m., smith, J. N. and williams, R. T. (i956). Studies in detoxication 6o. The metabolism of alkylbenzenes. Biochem. 7., 64, pp. 50-56.

EMERSON, P. A. and NICHOLSON, J. P. (I 965). The absorption of $4: 4^{\prime}$ Diisoamyloxythiocarbanilide (Isoxyl) using radioactive material (S.35 tagged). Trans. 24th Research Conference in Pulmonary Diseases, pp. 45-46. Veterans' Administration: Washington.
FEWSTER, M. E. and HALl, D. A. (I95I). Application of buffered solvent systems to the detection of aromatic acids by paper chromatography. Nature, Lond., r68, pp. 78-79.

KING, E. J. and wootton, I. D. P. (I956). Microanalysis in Medical Biochemistry, p. I6 I. Churchill: London.

KRADOLPHER, F. and SCHMid, K. (I 962). The chemotherapeutic activity of injected DPT (Ciba I 906). Leprosy Rev., 33, pp. I I-I 9 .

MILbURN, P., SMith, R. L. and Williams, R. T. (ig64). Biliary excretion of foreign compounds in the rat. Biochem. 7., 96, 5 P.

Ross, c. м. (1963). Annual Report, East African Leprosy Research Centre, I962-1963. E.A. Common Services Organisation, Nairobi.

SCHMID, K. and TRIPOD, J. (I 959). Experimental investigation of the absorption and excretion of Ciba igo6 (DPT). Leprosy Rev., 30, pp. 85-97.

Williams, R. T., millburn, P. and smith, R. L. (i965). The influence of enterohepatic circulation on the toxicity of drugs. Ann. N.Y. Acad. Sci., 123, I I O-I 24. 